\title{
Apresentação do Dossiê Crítica à Economia Política, Trabalho e Educação no Capitalismo.
}

Este dossiê resulta da articulação acadêmico-científica coordenada pelo Laboratório de Estudos do Trabalho e Qualificação Profissional (LABOR) da Universidade Federal do Ceará, reforçando a articulação e nucleação de estudos, pesquisas e divulgação científica.

A interação entre esses pesquisadores, seus grupos de pesquisa e seus programas de pós-graduação, em articulações de trabalhos conjuntos, pesquisas em comum e outras atividades acadêmicas compartilhadas, tem como base a perspectiva crítico-social e emancipatória da Educação e sua relação com o desenvolvimento social, econômico, tecnológico, político e cultural do Brasil e do mundo. Desta forma, a produção científica decorrente desses estudos, e que é agora trazida ao público nesse dossiê, contemplou de forma geral a abordagem da Educação, situada como complexo social articulado com os demais complexos sociais (produção, trabalho, cultura, política etc), formando uma totalidade societária contraditória e conflituosa, concatenada como unidade, apesar do aparente estilhaçamento das formas sociais e de suas manifestações culturais.

Nesta edição, um dos eixos basilares se refere às transformações recentes do Modo de Produção Capitalista, tanto em seus aspectos econômicos, quanto societários, expressos em políticas gerais, educacionais, formação humana e qualificação profissional. Como elemento de unidade dentro da pluralidade de objetos abordados, encontra-se a perspectiva crítica, dialética, e o referencial do Materialismo Histórico, como ferramenta analítica, e a concepção de Formação Humana Integral, como referencial para os processos formativos geral e educacional em sentido estrito.

A Formação Humana Integral, como concepção educacional formativa, elabora o projeto de formação do ser humano trabalhador para além das limitações postas pelo projeto formativo burguês. Se o projeto burguês acena com a possibilidade, ainda que limitada, de formação diferenciada para a elite e um projeto subalterno e castrador do desenvolvimento das classes trabalhadoras, a concepção de Formação Humana Integral supera, no sentido mais pleno da superação dialética (nega e vai além, incorporando o que supera), o modelo formativo capitalista. Essa 
perspectiva ampla, omnilateral, crítica e radicalmente humanizadora, se encontra expressa e desenvolvida como base analítica de vários dos artigos aqui apresentados.

Por outro lado, escola e sistemas educativos não são os únicos espaços de formação dos trabalhadores. Vários outros campos de atuação humana se constituem em espaços formativos e, consequentemente, educativos. O fenômeno educativo é pensado nas pesquisas e estudos apresentados neste volume numa perspectiva dialética, dessa forma, integrado ao processo de produção e reprodução social amplo. Assim sendo, a rigor, todas as instituições e práticas sociais são compreendidas como locus de processo educativo. Todo processo social e suas práticas desenvolvem saberes e relações entre os trabalhadores e entre estes e as outras classes e instituições sociais.

Esta edição reflete igualmente, e de forma clara, deliberada, consciente e propositiva, o momento histórico particularmente conflituoso vivido pela sociedade brasileira e mundial. Mais que apenas um período conflituoso, a crise do Bloco Histórico anterior, o qual evidenciava a emergência política dos movimentos sociais e populares, entre eles as classes trabalhadoras da cidade e do campo, permitiu a emergência de sua alternativa contraditória reacionária.

O conservadorismo das elites sociais foi tensionado por ação política e pela propaganda financiada por grupos plutocráticos da direita dos EUA e do Brasil, massificada pela mídia e pelas redes sociais digitais, engendrando a ascensão de uma direita de cunho fascista. Essas elites tem levado ao poder político facções marginais que, pouco tempo atrás, não se supunha plausíveis, que procuram implementar políticas públicas abertamente reacionárias, em vários flancos sociais e econômicos. Com essa emergência reacionária ficou evidenciada a permanência (realimentada, induzida e propagada) do racismo, da misoginia, da intolerância quanto à opções de gênero, de sexualidade, de credo religioso, entre outras questões importantes.

Os estudos representados nesses textos destacam a importância de alternativa ao modo de organização da produção da vida, do trabalho, do processo educativo em geral, e da escola entre outros espaços, instituições e processos sociais 
como campos de resistência ao controle sobre o saber, ao cerceamento ideológico destilador de ódio e intolerância que ganhou evidência nos últimos anos, e contra o qual se faz necessário resistir. A Revista Labor, assim, assume seu caráter crítico e engajado, como condição fundante e necessária a uma academia e ciência social verdadeiramente emancipatória e voltada ao desenvolvimento pleno do ser humano, o que implica a necessária crítica a tudo aquilo que obstaculize ou combata os potenciais humanizadores de cada grupo social ou classe, com sua cultura e suas particularidades.

A perspectiva crítica e emancipatória da revista enseja ainda análises acerca da formação humana e de suas expressões e manifestações em campos sociais como o trabalho, o desenvolvimento econômico-social e cultural, o direito, a psicologia do trabalho, estudos sociológicos gerais e de sociologia do trabalho, bem como das áreas de serviço social e de políticas públicas, áreas e subáreas de estudo. O presente dossiê também incorpora essas produções analíticas variadas, assumindo um cunho multidisciplinar e plural, permitindo um apanhado rico da complexidade dos processos sociais em curso no país e no mundo.

Prof. Dr. Enéas de Araújo Arrais Neto

Profa. Dra. Elenilce Gomes de Oliveira 